\title{
A PLEA FOR CONSERVATION OF THE BALD EAGLE IN SASKATCHEWAN
}

\author{
by D. Wayne Davis, Dept. of Zoology, University of Arkansas, Fayetteville
}

There is a growing concern among naturalists and conservationists about the welfare and future of the Bald Eagle (Haliaeetus leucocephalus) in North America. Poisoning from predator baits, a lowering of reproductive performance by pesticides, illegal shooting, breaking of eggs and killing of young, chopping down of nest trees, and destruction of habitat, all probably have contributed to the drastic decline in numbers of this magnificent bird. Northern Saskatchewan is one of the remaining great inland nesting areas of the Bald Eagle. However, unless appropriate steps are taken to insure the survival of this bird, it may face extirpation even in this remote region during this century. It is the purpose of this paper to report some observations of Bald Eagles, to cite examples of predation by man on this bird, and to offer suggestions for preventing their destruction.

The information presented herein was gathered by me from 1960 to 1966 during a mammal survey and a study of the ecology of the Northern Flying Squirrel and the Red Squirrel. These projects were supported by the Institute for Northern Studies at the University of Saskatchewan, the U.S. National Science Foundation and the Wildlife Branch of the Saskatchewan Department of Natural Resources. Thanks are due to W. H. Beck, C. L. Ferguson, C. S. Houston, D. James, R. W. Nero, several conservation officers, trappers, commercial fishermen and many others. Thanks are also due to the Saskatchewan Natural History Society for allowing me access to their Prairie Nest Records Scheme.

A number of authors have referred to an appreciable reduction in Bald Eagle numbers, especially of the subspecies Haliaeetus leucocephalus leucocephalus (Linnaeus), which occurs from Eastern Canada to Mexico. The subspecies found across the northern U.S. and Canada, H. $l$. alascanus
Townsend, may be increasing in number in Alaska where legislation protecting this bird was passed in 1952 (Imler and Kalmbach, 1955). Prince Philip recently referred to the Bald Eagle as a bird in danger of becoming extinct. Alexander Sprunt IV, Director of Research for the National Audubon Society, says, "The Bald Eagle is probably undergoing a slow decline" (Dunkeson, 1966). Persecution of the eagle in Canada is no recent event as attested by Taverner (1934) who wrote:

"Throughout Canada, except on the seacoasts, the Bald Eagle is nothing more than a rare, interesting, and picturesque feature of the landscape. It is greatly to be regretted that it is usually a target for every gun when it comes within range."

Taverner's remarks may be applied to northern Saskatchewan where residents often have bitter feelings against the eagle. Even though Saskatchewan has a law which makes it illegal to kill a Bald Eagle (Anonymous, 1960), many Bald Eagles still fall victim to man each year, either through ignorance or unconcern for this law. I have become convinced that Man is a major predator on the Bald Eagle, as indicated by the following observations.

\section{Predation by Man}

The comments and incidents listed below happened in Saskatchewan's northland. Similar incidents take place each year and at a rate which must have a strong effect on the eagle population.

DNR employee: "I take a pot at them when I can get close enough."

Mr. Jim Good, Stony Rapids: "Trappers here kill eagles whenever possible; this is no easy job since they are very wary old birds."

White trapper and partner: "One spring we destroyed three nests and six eggs while trapping muskrat and 
beaver. One man I knew would cook and eat the eggs. I usually chop down trees and destroy the eggs or young and shoot the adults. Few old birds are killed because they stay out of gunshot range."

Indian (age 18): "I have chopped down about three nest trees with young eagles while I was with other people. I have never destroyed a nest while alone."

Mrs. J. K. Johnson, Big River-Cree Lake: "An eagle nest at Chartrand Point, called Eagle's Pass at one time, was cut down by the natives. It was a partially dead jack pine or black spruce."

Fishing lodge operator at Cree Lake: "Two fishermen from the States came back to camp one night just seething. because they had found a Bald Eagle dead on the shore. Someone had shot the eagle a day or two before."

Resident non-trapper: "I shoot at eagles when I get the chance." He told me that during the summer of 1964 he shot at an eagle but did not kill it.

One trapper told me of a 70-yearold Indian who had killed many eagles in his career as a fishing guide, trapper and fisherman. "The man kills every Bald Eagle and destroys every nest he sees."

Boys, 14 and 16: These boys told me that they had shot at eagles during the summers of 1964 and 1965. In the area where they had shot at the eagles an osprey nest was found. Apparently they were not able to distinguish between these two species.

During 1965, two young eagles were taken from a nest. The tree was chopped down and destroyed. These eagles were hand raised. Later one was found dead in Manitoba (Davis, 1966). The death of this eagle is not surprising since it was hand raised and therefore not properly trained in caring for itself.

\section{Reasons Why the Bald Eagle is Hunted and Destroyed}

Trappers and fishermen have various reasons for destroying Bald Eagle nests and shooting the adults. One trapper I talked with is convinced that the Bald Eagle destroys muskrats. He gave the example of a large muskrat population which, according to the trapper, was destroyed by a pair of Bald Eagles nesting nearby. John Hanson of Cree Lake told me he once saw a Bald Eagle catch a muskrat. Another Cree Lake trapper, Martin Engeman, saw a Bald Eagle harassing a Red Fox which was attempting to cross a frozen lake. A Stony Rapids resident stated: "Trappers hate these eagles due to the fact that they destroy a lot of small furbearers such as mink and muskrat." The bitterness held against the Bald Eagle is probable due to overly emphasized facts and exaggerated or questionable incidents. Some trappers feel the young eaglets are fed a high percentage of furbearers, but examination of nests does not bear this out. There is no question that the eagle will occasionally take valuable furbearers, but it seems doubtful if any great or lasting damage is done to any mammal population. Herrick (1927) and Imler and Kalmbach (1955) report that Bald Eagles may take small mammals. Imler and Kalmbach, however, feel that in most cases they exert little influence on a mammal population. They found that oneeighth or more of the eagles' food was carrion. Schondelmeier (1965) of Jansen, Saskatchewan, reported a Bald Eagle feeding on the carcass of a cow on April 11.

Bald Eagles in Saskatchewan seem to feed primarily on fish and many of these birds are seen hunting along the shorelines. The skeletons of northern pike and suckers were found under a nest tree at Cree Lake (Davis, 1966). Heidelbauer (1966) also found fish in a Bald Eagle's nest at Weitzel Lake. Aschim (1965) and B. Richards (pers. comm.) reported eagles catching large fish. W. H. Beck and I visited four nest sites (two sites with young eagles) at Cree Lake in June 1966. One nest contained three half-eaten 10-inch common whitefish. Another nest contained many fish scales. At the base of three nests we found 19 fish bones and three breast bones of birds which were of duck or mergan- 
ser size. Five of these 19 bones were those of northern pike. No mammal remains were found.

In Saskatchewan the Bald Eagle probably takes few fish of economic importance. Certainly the dollars and cents value of the Bald Eagle as a tourist attraction and as part of the northern heritage repays many times over the small damage done to fish and mammals.

Unfortunately, many eagles are killed and nests are destroyed by men and boys who are not trappers or fishermen. The killing of an eagle is a status symbol to many northern youths. Also, as more city residents invade the north each summer, youngsters and grownups alike pour into the lake areas with guns and often use them indiscriminately. I have seen muskrats, red squirrels, gray jays, loons, ravens, and spruce grouse shot because they were convenient and challenging targets. Heaslip (1959) also reported that raven and grebes were found shot during the spring near Uranium City. Certainly an eagle would be shot by these same people if the opportunity arose.

In the early winter of 1965 someone shot and killed a Bald Eagle in Michigan. The comments of John Grey (1966), editor of Michigan Conservation, could well apply to those people in Saskatchewan who would destroy the Bald Eagle:

"Whoever you are, you killed a Bald Eagle. Few hunters could duplicate what you did . . because there are just about no Bald Eagles left in Michigan. And their number is diminishing all too fast over the entire continent . . Whoever you are, whatever you are, certainly you are no sportsman. And mister, no conservationist anywhere speaks in your behalf. Sportsmen and conservationists pity you, whoever you are. They pity you because you miss the indescribable thrill of being in the woods with a gun. The ethic of an age-old sport is obviously not yours to enjoy. You have no appreciation of the true rewards of hunting. Established is the fact that you are a violator. But somehow you are more or less than that. You killed a Bald Eagle."

\section{Poisoned Bait Sets}

Another mortality factor caused indirectly by man results from eagles feeding on poison baits set out for wolf control.

A few years ago, C. L. Ferguson, then a pilot and conservation officer for the D.N.R., sighted six Bald Eagles feeding on poisoned meat placed on lake ice for wolves. The bait was on a lake north of Uranium City near the N.W.T. boundary. "When approached the eagles flew off as if in a drunken stupor." If the eagles were lucky they only became sick. More likely these eagles and others like them fell into the forest and died and were never counted as a casualty of poisoned bait sets. However, at least seven Bald Eagles have been found dead at poisoned baits, according to C. L. Ferguson and Bill Richards:

Two juveniles died at a bait set northwest of Besnard Lake. An adult was killed at Nagle Lake and was given to the Saskatchewan Museum of Natural History.

Two adults were found dead at Irving Lake (east of Stanley). One of these eagles was mounted and is now in a private home.

Two immatures were killed by poisoned meat on the west side of Triveet Lake.

Many other animals have been killed at bait sets. Fourteen foxes were counted dead at one set by C. L. Ferguson. At other sets, lynx, mink, wolverine, gray jays, raven, and other animals have been found.

Poisoned bait for wolves (fresh meat treated with strychnine) is set on lake ice well away from the shore. B. Richards and G. Neis state that a few eagles overwinter in the southern part of the coniferous forest. Other eagles return from their southern wintering grounds about March 15 . Since Bald Eagles are carrion eaters, they are drawn to the poisoned meat during the winter and early spring when fish are not available. This hazard could be lessened if the pois- 
oned bait was burned or buried by March 1, rather than waiting for it to fall through the ice which often does not occur until June 1.

\section{Conclusions and Suggestions for Protecting the Bald Eagle}

As a result of talking with residents and from personal observations I must conclude that the Bald Eagle population in Saskatchewan is declining. The first and obvious action which can be taken is to stop the destruction of nests and the killing of nestlings and adults. Later, other steps such as prohibiting motor boats and camping in certain areas might be taken to insure the maintenance of a safe population. Many Bald Eagles now winter on the large waterfowl refuges in the U.S.A. At least 300 Bald Eagles overwinter on the wildlife refuges of Missouri (Dunkeson, 1966). These areas help the eagles safely spend the winter with a minimum of hardships. Thus, the protection of this species during the most critical time, the reproductive period, should pay dividends.

I would also like to stress that no Bald Eagle should be removed from the nest for any purpose. An eagle taken from the nest and raised by hand misses the parental training and care. It certainly would have less fear of man and would be more susceptible to shooting or poisoning.

A very serious factor is that the area of the Bald Eagle's nesting territory is being reduced. Emma Lake, Madge Lake and other small lakes in the southern part of the coniferous forest will probably never again be the site of an eagle's nest. Lac la Ronge, Candle, Wollaston and other lakes are in danger of losing the eagles which nest in these areas. Bald Eagles cannot compete with motorboats, water skiiers, and curious onlookers. As woods are cleared and cabins and lodges built, the eagles are forced to find new nesting sites. Fortunately, Bald Eagles may use the same nest year after year. In areas frequented by many people, safety zones of one-quarter mile radius around the nest could be marked off.
Recently, the Saskatchewan Natural History Society passed a resolution to review the status of the Bald Eagle in northern Saskatchewan. The Department of Natural Resources was asked to undertake an educational program among northern residents and visitors as to the value of the bird and the need for protection. The resolution asked that the present laws be publicized and enforced when necessary (Slimmon, 1966). I have restated parts of this resolution and made some additional suggestions in the following:

1. Begin an educational program to inform northern residents and visitors as to why they should not kill eagles and destroy nests. Inform them of the provincial law protecting this bird. (Almost no one I talked with, including some D.N.R. patrolmen, knew of the existence of this law. Many northern residents still feel that the D.N.R. looks favourably on the shooting of this bird.) Educational pamphlets could be published by the Department of Natural Resources $A N D$ The Saskatchewan Natural History Society. Personal contacts with northern residents should be made whenever possible.

2. The law prohibiting the shooting of the Bald Eagle and the disturbance of a Bald Eagle nest should be enforced. Enforcement in the past has been a serious problem. Government ministers have told conservation officers to "go easy" on law enforcement in the north and northern conservation officers have been given little direction about enforcement. One conservation officer told me he often "played it cool" and did nothing because he had not been properly directed. A trapper informed me that a conservation officer caught him shooting an eagle and did nothing. Conservation officers should be given full support by the D.N.R. and other government agencies when enforcing this law. Appropriate steps should be taken against all offenders.

3. Poisoned meat sets for wolves should not be set out before Decem- 
ber 1, and should be buried or burned by March 1. The practice of poisoning wolves should be reexamined and poisons should always be used with discrimination.

4. A permit should be required to keep the Bald Eagle in captivity and then only in well-managed public zoos.

Some Observations of Nest Sites and Reproductive Success of the Bald Eagle in Northern Saskatchewan Some measure of the status of the Bald Eagle in Saskatchewan may be obtained by documenting nest sites, eggs and young. It is hoped that the following unpublished observations, together with records previously published, will provide a basis for future assessment of the Saskatchewan population.

The following items are in geographic order from south to north:

Parrhill Lake - north of Norquay: (Pers. comm., Dr. Stuart Houston) "The nest was found by Bill Horseman in mid-June, 1965. He and I visited the nest June 20; Bill climbed the tree and applied the band. The flat-topped nest was four feet deep and five feet wide. It was constructed of sticks $1^{\prime \prime}$ in diameter and was lined with marsh grass. Location: $52^{\circ} 20^{\prime} \mathrm{N}$ and $102^{\circ}$ $10^{\prime} \mathrm{W}$ (in terms of $10^{\prime}$ blocks)."

Emma Lake: The following accounts were given to me by Mr. George Neis of Emma Lake. "About 1950, an eagle was seen feeding on a deer that two coyotes had chased and killed out on the ice in front of our house. Between 1955 and 1958, I saw two eagles. One was flying and the other eating on a deer about two miles northwest of here (Neis Beach). About 1955 I saw two Bald Eagles building their nest 50 yards from the shore of Emma Lake. The nest was located 60 feet up in a large white poplar across the bay north from Dr. McPhail's cabin. It must have been April since the snow was beginning to melt. I would say that the Bald Eagles stay here the year around."

"On May 12, 1961 I spotted a lone adult Bald Eagle on the shore near Munson's Bay. A large nest 40 feet up in a white spruce was found nearby.
The nest was approximately 30 yards from the lake edge. The eagle was seen in this area several times that spring, but it was always alone and no activity at the nest was noted."

Big River: (Pers. comm. Mrs. J. K. Johnson, Big River). About 15 years ago Mrs. Johnson's son, George, found an eagle's nest about three and onehalf miles from Big River. She did not know if the nest was still in use.

Candle Lake: On July 9, 1958 Elmer L. Fox of Regina found an eagle's nest 40 feet up in the top of a black spruce on Spider Island. One wellfeathered young was in the nest (Prairie Nest Records Scheme).

Whiteswan Lakes: On July 12, 1959 a nest tree was found blown down and one young in the nest was killed. On the same day an eagle was seen at another nest (P.N.R.S.).

Cumberland House: R. Mackay of La Ronge told me that in recent years a nest had been along the river by the Birch River Settlement. Eagles were often seen flying near Macdonald's Bay on Lake Namew although no nests were found.

Prince Albert National Park: On June 25, 1958 A. M. Pearson found a nest with one young on the Kingsmere River. The nest was located 35 feet above the ground and was made of sticks, grass, and reeds (P.N.R.S.) "There was a nest at the Narrows, Waskesiu Lake, near the start of the portage to Kingsmere Lake. The nest was 50 feet up in a Black Poplar. Two young were raised this year (1965)." (Dr. Stuart Houston.)

There were two well-feathered young in this same nest on August 8, 1966. By August 13 one young had left the nest (Stanley Shadick, Saskatoon).

Amisk Lake: On July 11, 1959 Elmer L. Fox observed a Bald Eagle sitting on a nest located on an island in Amisk Lake (P.N.R.S.).

Lac la Ronge: Burns (1961) reported seven family sites on La la Ronge in 1961 as compared to four in 1960 . Bill Richards says there are now probably three pairs nesting on Lac la Ronge.

Little Deer Lake: G. Koshinsky of La Ronge found an eagle's nest on the largest island in Little Deer Lake 


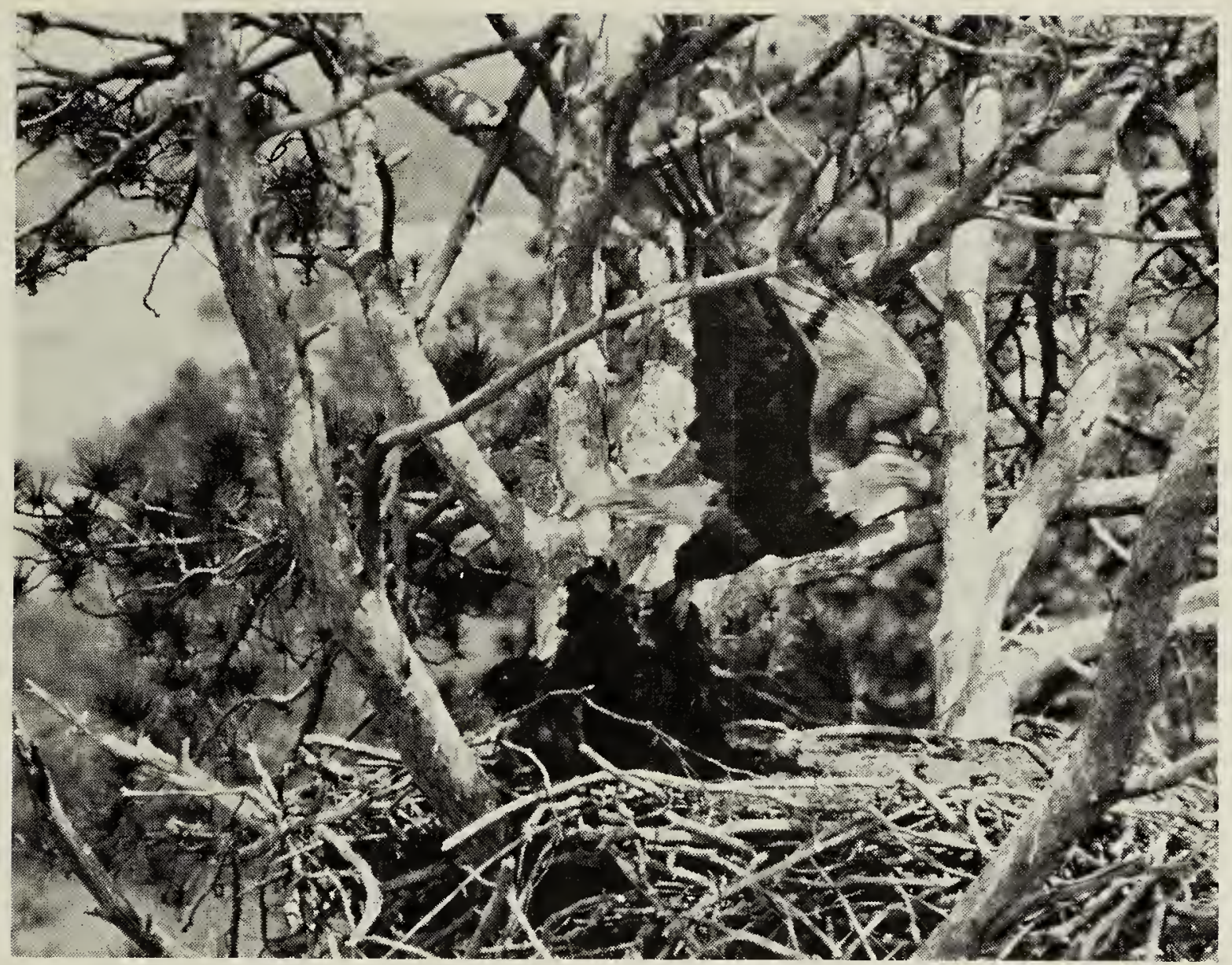

Photo by C. J. Henry, courtesy U.S.D.I.

Bald Eagle, Seney Refuge, Germfask, Michigan

(33 miles north of La Ronge). The nest is located 25 to 30 feet up in a spruce. It has been occupied since 1962.

Otter Rapids: A recently occupied nest was observed in early July, 1965 on the face of a cliff about 30 feet above the water on a small river $8 \frac{1}{4}$ miles ENE of Otter Rapids $\left(55^{\circ} 40^{\prime}\right.$ $\left.\mathrm{N}, 104^{\circ} 30^{\prime} \mathrm{W}\right)$, reported by Dr. Johnston of Prince Albert. When visited by Doug Whitfield and Jonathan Gerrard on July 1, 1966 there were no signs of occupancy.

Alongside Highway \#2, which was still under construction and not open to general traffic, was another nest, three miles north of Otter Rapids $\left(55^{\circ} 42^{\prime} \mathrm{N}, 104^{\circ} 38^{\prime} \mathrm{W}\right)$. This nest was 40 feet up in a live poplar tree and was evidently deserted when visited by Jonathan Gerrard and Doug Whitfield on July 4, 1966. A construction worker reported that it had been occupied until three weeks previously and he was not aware what had happened to the birds. The tree was so close to the right-of-way that it had been scraped by the construction machinery.
Sulphide Lake: Vern Studer of La Ronge told Gerrard and Whitfield that Bald Eagles had nested on the lake $55^{\circ} 22^{\prime} \mathrm{N}, 104^{\circ} 52^{\prime} \mathrm{W}$ ) for many years and he thought they were there again in 1966. The nest is in a tall poplar tree.

Hickson Lake: Professors E. M. Nanson and H. P. Kent of Saskatoon located a nest on an island in the lake $\left(56^{\circ} 20^{\prime} \mathrm{N}, 104^{\circ} 22^{\prime} \mathrm{W}\right)$ on July 6 , 1966. The nest was on the top of a 30 -foot dead stub and contained two feathered young.

Besnard, Sucker, and Head Lakes: About 1958, Folke Lindsgog showed Conservation Officer C. L. Ferguson the location of six nests on Sucker Lake. The eagles began to disappear until there may not be any nests on Sucker Lake at this time. Occasionally an eagle is seen and Conservation Officer Bill Richards of La Ronge feels there may be two or three nests there and along the river. One man at Sucker Lake raised eagles and kept the juveniles chained. He felt they probably came back the following spring. C. L. Ferguson has seen eagles in the Besnard, Head, and 
Sucker Lake region as early as midMarch.

Pinchouse Lake: During the early 1960's a pair of Bald Eagles nested for three years at a small lake east of Pinehouse.

Ile à la Crosse: "An old telegraph tower served as a support for a nest for a number of years. It fell down about 1961" (C. L. Ferguson). A few years ago a mink rancher raised an eagle and kept it in a cage.

Churchill River: C. L. Ferguson told me they were quite common in this area in 1964. (Pers. comm. Dr. Stuart Houston): "Dr. Bob Cram took a party of boy scouts from Ile à la Crosse down the Churchill River to La Ronge, via Nemeiben Lake. The trip lasted six days, from July 25 to July 31,1965 . The party did not see a single eagle. In earlier years, Cram sighted about two per day on the river."

Clear Lake: (North end of Churchill Lake where it connects with Frobisher Lake) Ted Pedersen, a D.N.R. patrolman, said Bald Eagles were once common on "Eagle Island". The eagles stopped nesting there about 1958 or 1959. Pedersen feels the eagles were driven away by shooting and harassment by the people at Clear Lake Village. Occasionally, an eagle is still seen at the lake.

Careen Lake: Mr. George Nelson of Saskatoon, a trapper at Black Birch Lake for many years, told me that a pair of eagles nested for several years on the shelf of a cliff along the Clearwater River one mile from the Black Birch River mouth. They were still there about 1960 . He has seen a nest or two on Careen Lake and said the tourist fishermen always enjoyed going by the eagle's nest. George did not see any eagle's nest on Black Birch Lake, although he did observe some adults.

Reindeer Lake: A few years ago the owner of a tourist fishing camp kept Bald Eagles as a tourist attraction.

Cree Lake: Eagles at Cree Lake have been reported by Lahrman (1964) and Davis (1966). W. H. Beck and I visited this area again from June 16-27, 1966:
June (2nd week): Some members of the staff at the Cree Lake Fishing Lodge found a dead Bald Eagle on the shores of MacIntyre Lake.

June 24: Two nests at the southeast side of Lazy Edward Bay built in 1965 and never used (Davis, 1966) were still vacant. Feathers and droppings indicated that they frequently had perched nearby. An adult Bald Eagle was seen at the far end of the small lake.

June 25: Beck and I travelled to Morrison Island where eagles had successfully raised a pair of young in 1965 (Davis, 1966). A new nest had been built about 60 yards away. The nest, located 30 feet up in a living hollow jack pine, contained two large down-covered young. The two eaglets were banded.

June 26: During the spring of 1966 a pair of Bald Eagles built a new nest on the northwest side of Middleton Island a few yards from Rushmer Channel. The nest was 25 feet up in a hollow living jack pine. (Two partially feathered eaglets were banded). A hole was found in the trunk and young birds, probably flickers, were heard inside.

Engemann Lake: Trapper John Hanson told me there were several nests along some of the rivers running into Engemann Lake.

Wollaston Lake: R. Lein and R. Sanderson in 1964 found only one nest on the lake and it had been chopped down. Apparently the Indians chop down every nest tree they see (Nero, 1966).

Hatchet Lake: In September, 1964, some sportsmen took a fishing trip to Hatchet Lake, Saskatchewan. The sight of a family of Bald Eagles nesting within view of the fishing camp was one of the highlights of their trip (Ellis, 1965).

Lake Athabasca area: Nero (1963) listed the Bald Eagle as a common summer resident. Nero was in the area again on June 30,1963 and saw three birds on nests. These new nests were located four miles west of Engler Lake, four miles southeast of Fir Island in Black Lake, and at the mouth of the Otherside River, Lake 
Athabasca. F. A. Heidelbauer had an active nest on an island in Riou Lake in 1963 (P.N.R.S.).

In 1964, F. A. Heidelbauer (pers. corres. to R. W. Nero) reported "eight active Bald Eagle nests were observed in the Richards-Engler-Riou Lake chain, southwest of Stony Rapids."

On July 15, 1964, M. Ross Lein and Gary G. Anweiler located an active nest on a cliff along the Porcupine River below Grove Lake (about 59 ${ }^{\circ}$ $20^{\prime} \mathrm{N}, 104^{\circ} 30^{\prime} \mathrm{W}$ ) (Nero, MS).

Mr. Jim Good of Stony Rapids sent this information to me:

"I have seen the same pair nest for several years down at the harbour on the north shore of the Fond du Lac River about twelve miles west of Stony Rapids. At first the nest was in a dead jack pine snag but eventually the snag fell down and they nested for a couple of years on a ledge of rock in the same area. I did not see the nest occupied during the summer of 1965 , but I saw an adult flying in the area, so perhaps they moved their nest somewhere nearby. I am advised that they prefer sandy areas or where sand is readily available and avoid solid rock areas. There seems to be few eagles north of Stony Rapids. They stay quite late in the fall and are occasionally caught in traps during November. When cold weather comes they fly south and return again in May. One trapper near here observed six families along a 25-mile stretch of a river. I believe there is a nest near Pine Channel."

\section{Nests and Number of Young}

Nests-In Saskatchewan Bald Eagles nest in jack pine more often than in any other tree. Of 30 recorded nests, 12 were in jack pine, five in white spruce, two in black spruce, one in a spruce (sp.), three on cliff ledges, two in poplar (sp.), and one in each of black poplar and white poplar, white birch, dead stub, and on a telegraph pole. The eagles also nest more often in live rather than dead trees, though this doesn't necessarily suggest living trees are sought out since there are fewer dead trees. Living trees would offer more protection from the weather, however. Seven of the 12 nests in jack pine were in living trees, three were in dead trees, and no information is available for the other two trees. The average height of 20 nest trees was 31.9 feet. Bald Eagles nest near water. The mean distance from water of 12 nest trees from Athabasca (Nero, 1963) and Cree Lake (present study) was about 35 yards, ranging from three to 133 yards.

Number of Young-Bent (1937) wrote that two or three eagles are hatched, but three are seldom raised and often only one grows to maturity. Twenty-one nests observed in northern Saskatchewan had a total of 35 young or an average of 1.67 eaglets per nest.

\section{LITERATURE CITED}

American Ornithologists' Union. 1957. Checklist of North American birds. Fifth ed. Baltimore. $691 \mathrm{p}$.

Anonymous. 1960. Game Act revised to protect hawks and owls. Blue Jay, 18:127.

Aschim, A. 1965. Bald Eagle swimming. Blue Jay, $23: 187$.

Bent, A. C. 1937. Life histories of North American birds of prey. U.S. Nat'l. Mus. Bull. No. 167. 482 p.

Burns, K. R. 1961. Reports of Bald Eagles from Lac la Ronge. Blue Jay, $19: 173$.

Davis, D. W. 1966. Some observations of bird life at Cree Lake, Saskatchewan. Blue Jay $24: 80-85$.

Dunkeson, R. L. 1966. Missouri's outdoor almanac. Missouri Conservationist, $27: 16$.

Ellis, M. 1965. Where grayling gang. Field and Stream, Sept., Vol. 70.

Gray, J. 1966. Editorial. Michigan Conservation, $35: 16-17$.

Heaslip, $T$. 1959. Bird observations from Uranium City. Blue Jay, 17:57-58.

Heidelbauer, F. A. 1966. Bald Eagle at Weitzel Lake, Saskatchewan. Blue Jay, $24: 86$.

Herrick, F. H. 1927. The American Eagle at. Vermillion, Ohio - on the shores of Lake Erie. Western Reserve University, Cleveland, Ohio. $34 \mathrm{p}$.

Houston, C. S., and M. G. Street. 1959. The Birds of the Saskatchewan River, Carlton
to Cumberland. Saskatchewan Natural History Society Publication \#2, Regina. 205 p.

Imler, R. H., and E. R. Kalmbach. 1955. The Bald Eagle and its economic status. U.S. Gov't. Printing Office, Washington, D.C. Circular $30.51 \mathrm{p}$.

Lahrman, F. W. 1964. The bird life at Cree Lake, summer 1963. Blue Jay, $22: 7-8$.

Nero, R.W. 1963. Birds of the Lake Athabasca Regina, Saskatchewan. Spec. Pub. No. 5. S.N.H.S., Regina, 143 p.

Nero, R. W. 1966. Editorial. The remote northern wilderness. Blue Jay, 24 :cover 2, June, 1966.

Schondelmeier, A. 1965. Bald Eagle observation. Blue Jay, $23: 108$.

Slimmon, J. A. 1966 . Resolution \#2. Saskatchewan Natural History Society Newsletter, \#10, January, 1966 .

Taverner, P. A. 1934. Birds of Canada. Nat'1. Mus. Can. Bull. No. 72, Ottawa. 445 p. 